\title{
Cultivating Healthy Personalities: Iowa and the Midcentury White House Conference on Children and Youth
}

\author{
JENNIFER ROBIN TERRY
}

ON DECEMBER 3, 1950, 67 Iowans joined nearly 6,000 other Americans at the National Guard Armory in Washington, D.C., to participate in the Midcentury White House Conference on Children and Youth. ${ }^{1}$ The conference, the culmination of three years of preparations by Americans nationwide, was the largest child welfare and development conference that the nation had yet witnessed. Conference delegates (including such notables as Eleanor Roosevelt, Dr. Benjamin Spock, and Margaret Mead) gathered for what one reporter termed "a five day verbal marathon" of panels, workshops, and keynote speeches to discuss and debate the best methods for developing healthy personalities in America's children and youth. ${ }^{2}$ Conference goers sought to devise a national plan that would instill in America's young "the

\footnotetext{
I am grateful to the State Historical Society of Iowa for the research grant that gave this project substance; to Annals of Iowa editor Marvin Bergman for his kind and thoughtful comments; and to the anonymous reviewers who encouraged and prodded this project along as only those cloaked behind the veil of anonymity can do. I also thank Paula S. Fass for reading drafts, Natalie Mendoza for great conversation, and Carolyn Merchant for introducing me to the concept of the conservation of childhood. Finally, I must acknowledge and thank Laura J. Ping, who helped me to find "where the tall corn grows."

1. This article will refer to the conference alternately as the Midcentury White House Conference on Children and Youth and the midcentury conference.

2. "Our Opinion: The Mid Century Youth Conference," Chicago Defender, 12/16/ 1950.
}

THE ANNALS OF IOWA 75 (Spring 2016). (C) State Historical Society of Iowa, 2016. 
mental, emotional and spiritual qualities essential to individual happiness and to responsible citizenship." 3 In so doing, delegates attempted to tackle what they believed to be the single greatest task of their time: to ensure a more peaceful global future through the cultivation of children who would have the potential to live with one another in mutual respect and cooperation. ${ }^{4}$ It was an ambitious agenda, to be sure.

This article focuses on the pre-conference planning period and sets out to do three things. First, it seeks to reinforce the significance of the 1950 White House Conference on Children and Youth. The conference and its preparatory period marked a turning point in the nation's interest in children by drawing attention to issues surrounding child development and highlighting the perceived link between healthy personalities and good citizenship. Second, it adds to the limited existing literature on the White House Conferences. It is the first study to shift focus away from federal efforts and highlight the decentralized and democratic nature of the midcentury conference. It takes Iowa as its focus because the state was a leader in child development in the early twentieth century and an early adopter of the conference preparation process. Further, a discrete focus on an individual state's preparation reveals much about its residents' concerns about issues that stemmed from World War II. I contend that a state-specific study of the 1950 conference preparation period does much to inform us of the regional aftermath of the war and is as important for understanding the nation at midcentury as studies of federal activity. Finally, this essay argues that Iowans viewed the task at hand as a local, organic process designed to foster in children discrete identities and personal agency. The cultivation of the individual, Iowans believed, could be best achieved through grassroots

3. "Report of the Iowa Commission on Children and Youth," 7/17/1950, file: Correspondence 1950, box 1, Esther Immer Papers, State Historical Society of Iowa, Iowa City; Children and Youth in Iowa at the Midcentury: Report of the Iowa Commission on Children and Youth (Des Moines, 1951), 2; Melvin A. Glasser, "Midcentury White House Conference Gathers," The Child, December 1950, 78; Dean W. Roberts, "Highlights of the Midcentury White House Conference on Children and Youth," American Journal of Public Health 41 (January 1951), 98.

4. "Planning Conference for Children and Youth," Washington, D.C., 3/30/1948, 4-5, file: Iowa Commission on Children and Youth Memoranda, 1950-1960, box

2, Esther Immer Papers (hereafter cited as "Planning Conference"). 
efforts. Yet Cold War anxieties subsumed local solutions within federal programs that treated children en masse with the purpose of manufacturing a homogeneous citizenry that would defend the American way of life against Cold War threats. Ultimately, federal aspirations hijacked community vision. This article should be understood as a national story told through the lens of Iowans' efforts.

THE 1950 CONFERENCE was the fifth White House conference that dealt with childhood issues, but it differed significantly from its predecessors in scope and process. Prominent social welfare activists had come together for such conferences at roughly tenyear intervals since 1909, when President Theodore Roosevelt called the first White House Conference on the Care of Dependent Children. The early conferences were top-down affairs, sanctioned by the president, with agendas that viewed childhood through lenses of problems and despair associated with dependency, poverty, and poor health. Solutions targeted specific groups of children who were deemed unfortunate and in need of care, protection, and policing. Not until the 1940 Conference on Children in a Democracy did the emphasis begin to shift, as conference organizers grappled with how children could "best be helped to grow into the kind of citizens who will know how to preserve and perfect our democracy." 5

The 1950 conference agenda built on the notion that children were future political actors but approached it from a perspective rooted in the latest advances in child development and psychological theory based on a "whole child" approach. ${ }^{6}$ That is, rather than simply seeking to mitigate and ameliorate children's external and physical conditions (as had previous conferences), the 1950 conference grappled with finding ways to cultivate well-adjusted, self-actualized individuals who, once grown, would act in confidence and balance to lead the nation and the world to peace and

5. Franklin D. Roosevelt, "Address by the President of the United States," in Proceedings of the White House Conference on Children in a Democracy (Washington DC, 1950), 70.

6. "Iowa Commission on Children and Youth: Annual Meeting," file: Iowa Commission on Children and Youth Minutes, 1949-1956, box 2, Esther Immer Papers. 
prosperity. This whole-child approach was couched in psychological terms and articulated in the conference theme: "A Fair Chance at a Healthy Personality." 7

The first few White House conferences have received much attention from scholars who study Progressive Era child welfare movements. The earlier White House conferences are routinely credited for being the impetus for such notable accomplishments as the establishment of the U.S. Children's Bureau, the passage of the Sheppard-Towner Maternity Bill, and the conception of the Children's Charter. ${ }^{8}$ Yet the Midcentury White House Conference on Children and Youth has received little scholarly attention even though its agenda was far more expansive and its outcomes far more transformative than those of its predecessors. ${ }^{9}$

Only recently has historian Marilyn Irvin Holt drawn this conference from the shadows in Cold War Kids: Politics and Childhood in Postwar America, 1945-1960. Holt's work spotlights both the 1950 and 1960 White House Conferences on Children and Youth and uses them as a framework to explain increased federal intervention in American children's lives during the early Cold War period. ${ }^{10}$ She argues that Cold War anxieties animated efforts to build a better citizenry, though not through manipulation and fear tactics (as has become a common narrative of Cold War childhood history) but rather through empowerment and by providing quality education, health care, and enrichment opportunities. These were costly endeavors that many Americans felt necessitated and justified federal leadership and funding. Holt convincingly argues that most of the issues taken up by conferees did influence subsequent federal legislation and programs.

7. U.S. Children's Bureau, “The Midcentury White House Conference on Children and Youth: Why a conference? How will it work? What can it mean to you?" file: White House Conference on Children and Youth, box 3, Esther Immer Papers (hereafter cited as USCB, "Why a Conference").

8. Hamilton Cravens, Before Head Start: The Iowa Station and America's Children (Chapel Hill, NC, 1993); Kriste Lindenmeyer, A Right to Childhood: The U.S. Children's Bureau and Child Welfare, 1912-1946 (Urbana and Champaign, IL, 1997); Judith Sealander, The Failed Century of the Child: Governing America's Young in the Twentieth Century (Cambridge, 2003).

9. Roberts, "Highlights of the Midcentury White House Conference," 96-97.

10. Marilyn Irvin Holt, Cold War Kids: Politics and Childhood in Postwar America, 1945-1960 (Lawrence, KS, 2014). 


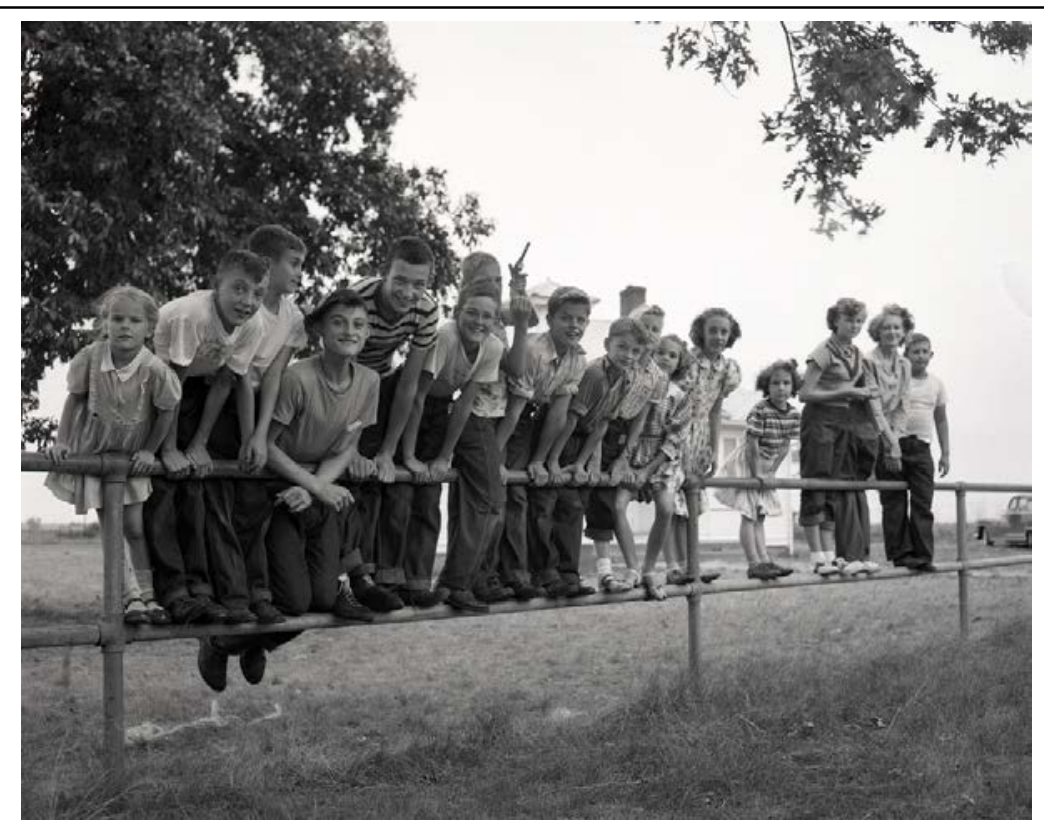

Conference delegates sought to ensure a more peaceful global future through the cultivation of children who would have the potential to live with one another in mutual respect and cooperation. Photo from A. M. Wettach Collection, State Historical Society of Iowa, Iowa City (SHSI-IC).

What she does not make explicit but should also be understood is that those catalyst issues were brought by state committees, prepared in advance, and presented to the National Committee on Children and Youth (NCCY). In this way, the 1950 conference differed in scope and process from the four preceding conferences. For the first time in the history of the conference series, a broad base of American citizens set the agenda through decentralized research and planning. Hence, the 1950 conference was celebrated as an exercise in democratic action-the purported hallmark of Cold War America.

FROM THE START, decentralized planning marked the 1950 conference as different from its predecessors. The NCCY was established to coordinate the efforts of federal agencies and state committees. It kicked off the process in 1947 by inviting American 
states, territories, and possessions to begin "at the grassroots" to assemble facts, data, and impressions on the conditions and needs of their children. ${ }^{11}$ The effort was touted as "a conference in progress" - a three-stage approach (assessment, conference, and followup) that would meet American children's needs in dynamic new ways. ${ }^{12}$ The NCCY considered this a "reverse approach" since previous conferences had served as the starting point for state and local action. By involving states in the early planning stages, the 1950 conference was far more inclusive than any prior.

What had once been a federal and special interest endeavor became, for the first time in its history, a regional, lay, and youthful enterprise. Nearly 100,000 people nationwide sprang to action, producing reports that were informed by racial, class, religious, and age diversity. ${ }^{13}$ A U.S. Children's Bureau pamphlet claimed that, "from its first stages to its last, the Midcentury White House Conference belongs to the people of the United States. It will be as dynamic as citizens everywhere make it." 14 The effort was celebrated as democracy in action. Conference chairman Oscar R. Ewing claimed that decentralized planning "represented a typically American approach to furthering one of our national ideals." 15 Americans across the nation answered the call to assess and document childhood in their local vicinity and took pride in the fruits of their grassroots efforts.

U.S. Children's Bureau chief Katherine Lenroot and NCCY chairman Leonard Mayo planned periodic forums where state representatives gathered to align goals and hone the 1950 conference agenda. State social welfare departments sent health and welfare representatives, state officials, and lay leaders to threeday planning conferences with themes such as "The Child in His Family and Community." Conference speakers emphasized local responsibility amid discussions that acknowledged children's significance to the national and global communities. At such mini-

11. Leonard W. Mayo and Katherine F. Lenroot to Mary Hunke, 11/3/1947, file: Correspondence 1948, box 1, Esther Immer Papers.

12. "Planning Conference," 2.

13. Platform Recommendations and Pledge to Children (Raleigh, NC, 1950), 13.

14. USCB, "Why a Conference," 2.

15. Edward A. Richards, ed., Proceedings of the Midcentury White House Conference on Children and Youth (Raleigh, NC, 1951), 2-3. 
conferences, Lenroot and Mayo encouraged states to submit wellresearched reports, from which they assembled the midcentury conference agenda. ${ }^{16}$ Throughout the planning years, the national committee served as a conduit for information and sent updates, requests, and reminders designed to encourage and maintain uniformity of purpose. However, when state planning committees wrote requesting federal funds and assistance, the national committee replied that planners should "tap local resources for money to finance their programs since the primary concern of the State Committees is the children within their own borders." National leaders also suggested that "services in lieu of funds are just as helpful as money." 17 The NCCY made it clear that democratic action included providing funding and resources. Thus, the task set before state delegates was broad: ascertain the physical, psychological, and spiritual conditions and needs of every child within their community while relying on goodwill voluntarism and creative financing.

IOWA formally established its supervisory and coordinating arm, the Iowa Commission on Children and Youth (ICCY), in October 1948. ${ }^{18}$ Three of the five delegates who had represented Iowa at the national planning conference-King Palmer, Ona May Breckenridge, and Esther Immer - were appointed to the ICCY Executive

16. "Planning Conference," 1-3. Iowa's five delegates were Mrs. H. C. (Ona May) Breckenridge, president of the Iowa Congress of Parents and Teachers; Dr. J. M. Hayek, director of Maternal and Child Health (State Department of Health); Esther Immer, Child Welfare Division (State Department of Social Welfare); King Palmer, Iowa Mental Hygiene Association, National Foundation for Infantile Paralysis of Iowa, and Iowa Welfare Association; and A. D. Wiese, president of the State Federation of Women's Clubs. "Iowa Commission on Children and Youth, 1949 Delegate Roster," file: Iowa Commission on Children and Youth Memoranda, 1950-1960, box 2, Esther Immer Papers; Des Moines Council of Social Agencies, "Case Work Division Meeting Minutes," 1/18/1950, file: Minutes 1949-1956, box 2, Esther Immer Papers (hereafter cited as "Case Work Division Meeting").

17. “Memo on State and Local Action," 4/25/1950, p. 2, file: Minutes 1949-1956, box 2, Esther Immer Papers.

18. "ICCY, Annual Meeting," 2; “Case Work Division Meeting," 2; "Iowa Commission Highlights: Needs of Children and Youth," 1/31/1950, p. 1, file: Iowa Commission on Youth Memoranda, box 2, Esther Immer Papers; Children and Youth in Iowa at Midcentury, 2. 
Committee. As the first statewide effort on behalf of children since the short-lived 1924 Code Commission (which followed the 1919 White House conference), the ICCY represented both the state government and the people of Iowa. Although the ICCY served to coordinate and facilitate efforts, Esther Immer (ICCY executive director and primary documentarian) acknowledged the significance of grassroots efforts when she wrote, "What is done in the local community, where the children really live, will determine the success of the project." 19 ICCY officers selected additional executive committee members, appointed specialized committees (including one composed of youth), and charged those committees with "finding the factors of ideal home life and inquiring into the way they can be applied and realized in the child's community relationships." ${ }^{20}$ For the ICCY, it was not enough to simply gather and analyze data. It sought workable solutions that would be implemented within children's communities, schools, and homes.

Across the nation, state participation and resource allocation ran a spectrum. For example, California, Maryland, and Oregon apportioned a significant amount of human and financial resources to the endeavor. They each produced highly professional reports that read much like the national proceedings. On the other hand, Hawaii produced a limited, six-page report devoted entirely to juvenile delinquency and noted that the state lacked the resources to enable it to conduct research. Iowa's resources fell somewhere in the middle, but the state was an early adopter of the project, had a proven track record on child welfare research, and was well organized. As such, representatives from several other states wrote to the ICCY as late as the spring of 1950 seeking advice on ways to organize committees and research efforts. ${ }^{21}$

19. “Iowa Commission Highlights," 1/31/1950, p. 1; “Case Work Division Meeting," 2.

20. “Iowa Commission Highlights," 1/31/1950, p. 1; "ICCY, Annual Meeting,"1. 21. King Palmer to Thomas R. Flynn, 5/3/1950, file: Correspondence 1950, box 1, Esther Immer Papers; Thomas R. Flynn to Esther Immer, 4/26/1950, ibid.; Community Research Associates, Mid-Century Study of Children and Youth in California (Los Angeles, 1950); Maryland Commission for Youth, Our Most Valuable Resource (Baltimore, 1950); Oregon Governor's State Committee, "News Bulletin" (1949-1952); Hawaii Commission on Children and Youth, Report (1950). 
Volunteers throughout Iowa, professionals and lay people alike, contributed labor and resources to the venture. Such efforts were instrumental to the commission's success as volunteers served on committees, conducted research, distributed questionnaires, held meetings and workshops, and publicized the ICCY and the midcentury conference in print and on radio broadcasts. Some state agencies contributed financially and even permitted the use of office equipment. ${ }^{22}$ Esther Immer noted the project's broad appeal when she recorded that roughly 250 of the 1,000 Iowans who attended the quarterly Iowa Welfare Association meetings "were laymen not connected professionally with any children's organizations." 23 Neighborhood groups throughout the state held small discussion groups at schools, churches, and homes to determine local needs. Professional researchers provided guidance in evaluating questionnaire results in order to assess whether the "youth of Iowa get the constructive care and guidance which will help them grow up into happy, well adjusted citizens, able to 'live and let live' in their generation." 24

Volunteers from the State Federation of Women's Clubs and University of Iowa graduate students distributed surveys to parents, teachers, and other adults, as well as children and teenagers in schools, correctional facilities, training schools, and youth organizations. Sometimes the response was overwhelming and "strained their facilities," as volunteers tabulated results by hand. Such was the case when 1,200 Fort Dodge residents responded. ${ }^{25}$

22. "Case Work Division Meeting," 3-4; Esther Immer to Dr. Robert E. Jewett, 1/16/1950, file: Correspondence 1950, box 1, Esther Immer Papers; "Iowa Commission Highlights," 2; King Palmer to Committee Chairmen, 2/27/1950, file: Correspondence 1950, box 1, Esther Immer Papers; King Palmer to Governor William S. Beardsley, 11/29/1950, file: Correspondence 1950, box 1, Esther Immer Papers; "Iowa Commission on Children and Youth: Progress Report" (January 1951), 1, file: Iowa Commission on Youth Memoranda, box 2, Esther Immer Papers.

23. Immer to Jewett, 1/16/1950; Esther Immer, "Proposed Report of the Iowa Commission on Children and Youth" (sent to the governor), 7/17/1950, file: Correspondence 1950, box 1, Esther Immer Papers.

24. Immer, "Proposed Report."

25. "Case Work Division Meeting," 3; Ray Bryan, Report of Committee on Employment of Youth (Des Moines, 1950), 1; Esther Immer to Mrs. L. J. O'Brien, 11/7/ 1950, file: Correspondence 1950, box 1, Esther Immer Papers. 
At other times, disagreements and misunderstandings arose. A number of people felt slighted when they were not selected for official seats on research committees (more than 1,000 people volunteered for a few hundred positions). ${ }^{26}$ Immer commented that some people were "disappointed because they felt that their recommendations carried no weight," and threatened to take their concerns to the governor. ${ }^{27}$

Yet, on the whole, volunteers came together in unity for the common purpose of considering how best to cultivate healthy, happy children. Immer alluded to volunteers' sense of pride and accomplishment with references to the "tall-corn song," claiming Iowa was "the best state in the land." Confidence ran high that the land "where the tall corn grows" would present "a betterthan-average level of achievement" at the national conference. ${ }^{28}$

THE FACULTY at the Iowa Child Welfare Research Station (ICWRS) provided "invaluable service" as consultants and lead researchers on a number of committees. ${ }^{29}$ The state-sponsored ICWRS was uniquely suited to the task. Its long-established purpose was to investigate "by the best approved scientific methods the conservation and development of the normal child [and] to make the resulting information available." 30 Historians Hamilton Cravens and Alice Boardman Smuts credit the institution with founding the field of child development. ${ }^{31}$

26. King Palmer to Committee Chairmen, 2/27/1950, file: Iowa Commission on Youth Memoranda, box 2, Esther Immer Papers; Intraoffice Communication, Esther Immer to Child Welfare Consultants, 3/3/1950, ibid.

27. Maude Broadfoot, "Field Report on the South East District Welfare Meeting and White House Conference Workshop," 3/13/1950, file: Iowa Commission on Youth Memoranda, box 2, Esther Immer Papers; Intraoffice Communication, Immer to Consultants, 3/3/1950.

28. "Iowa Commission Highlights," 1/31/1950, p. 1. Music and lyrics for the "tall-corn song": Ray W. Lockhard and George Hamilton, "Iowa Corn Song," (1921), at Iowa Digital Library, University of Iowa, http://digital.lib.uiowa .edu/cdm/ref/collection/sheetmusic/id/51.

29. Palmer to Flynn, 5/3/1950; "ICCY 1949 Delegate Roster."

30. Dorothy Bradbury, Pioneering in Child Welfare: A History of the Iowa Child Welfare Research Station, 1917-1933 (Iowa City, 1933), 14.

31. Alice Boardman Smuts, Science in the Service of Children, 1893-1935 (New Haven, CT, 2006), 117; Cravens, Before Head Start, x. Although both historians 
The research station was established at the University of Iowa in 1917 after a nine-year indefatigable campaign by Des Moines resident and Iowa Congress of Mothers founder Cora Bussey Hillis. She argued that a state known for its prize-winning horticulture and animal husbandry should also "give the normal child the same scientific study by research methods that we give to crops and cattle." 32 At every opportunity, Hillis reminded both academics and congressmen that children were Iowa's most valuable crop.

Subsequently, the research station established benchmarks for gauging and understanding children's physical, mental, and psychological growth processes and set a model for child research programs across the nation. Establishing norms by studying healthy children was a novel undertaking in an era when research and child welfare efforts focused heavily on social ills (as demonstrated by the earlier White House Conference themes). ${ }^{33}$

World War II had disrupted child development research at the ICWRS when many professionals were mobilized for defense work. In the immediate postwar period, the ICWRS struggled to regain lost ground. Under the leadership of Robert R. Sears, the station restructured, cut less fruitful programs, and focused on the burgeoning field of child psychology. ${ }^{34}$ ICWRS faculty (most notably Sears, Dr. Vincent Nowlis, Dr. Ralph Ojemann, Dr. Ruth Updegraff, and Dr. O. C. Irwin) worked on numerous projects that examined the intersection of children's actions, social constraints, and desire gratification as influenced by parenting, gender roles, and ordinal family positions. ${ }^{35}$ Their work contributed to a larger body of psychoanalytic research by scholars such as pediatrician Dr. Benjamin Spock and social anthropologist Dr.

chronicle the history of the ICWRS, neither mentions its significant role in the midcentury conference.

32. Cravens, Before Head Start, 7-9; Bradbury, Pioneering in Child Welfare, 5-7; Smuts, Science in the Service of Children, 121-32.

33. Smuts, Science in the Service of Children, 117; Bradbury, Pioneering in Child Welfare, 5 .

34. Cravens, Before Head Start, 221, 226-29; Smuts, Science in the Service of Children, 252.

35. Robert R. Sears, "Personality Development in Contemporary Culture," Proceedings of the American Philosophical Society 92 (1949), 363-66, 369. 
John Dollard who had claimed that authoritarian parenting was detrimental to children's personality development as it frustrated children and led to aggressive, antisocial behavior. ${ }^{36}$ Thus, it is easy to see why ICWRS director Sears would seize the opportunity to contribute to the national conversation at the midcentury conference.

In November 1948, Sears wrote to Esther Immer, offering to establish a 15-member research committee for the purpose of advising other ICCY committees. The ICCY wholeheartedly accepted the offer and appointed Sears to a position on its executive committee. ${ }^{37}$ Hamilton Cravens refers to Sears as a "thoroughly professional scientist with no particular political agenda." 38 Sears's actions in late 1948 and early 1949, however, appear to suggest political motives. By involving the ICWRS in the preconference planning, he brought attention and resources to a program that had been severely hampered by wartime measures. Further, within two months of installing ICWRS faculty on various ICCY committees, Sears took a faculty position at Harvard University and secured for himself a seat on the national conference's executive committee. That transition brought Sears into a direct working relationship with other top professionals (including Spock and Erik Erikson) on the national Technical Committee on Fact Finding and ensured that recent research conducted at the ICWRS would have an even greater voice in the national agenda through the midcentury conference. ${ }^{39}$

36. Sears, "Personality Development," 363; Robert R. Sears, "Ordinal Position in the Family as a Psychological Variable," American Sociological Review 15 (1950), 397-401; William Graebner, "The Unstable World of Benjamin Spock: Social Engineering in a Democratic Culture, 1917-1950," Journal of American History 67 (1980), 614.

37. Robert Sears to Esther Immer, 11/2/1948, file: Correspondence 1948, box 1, Esther Immer Papers; Robert Sears to Esther Immer, 11/30/1948, ibid.; Esther Immer to Robert Sears, 12/23/1948, ibid.; Esther Immer to Robert Sears, 12/27/ 1948, ibid.

38. Cravens, Before Head Start, 226.

39. Ibid., 247; Robert Sears to Esther Immer, 1/3/1949, file: Correspondence 1949, box 1, Esther Immer Papers; Esther Immer to Robert Sears, 1/8/1949, ibid.; Palmer to Beardsley, 11/29/1950; "Iowa Commission Highlights"; "ICCY 1949 Delegates Roster." Vincent Nowlis assumed Sears's ICCY leadership position when Sears left the ICWRS for Harvard University, where he worked with Talcott Parsons on a general theory of action. Joel Isaac, "Theorist at Work: Talcott 
THE MIDCENTURY CONFERENCE'S central theme, "A Fair Chance at a Healthy Personality," suggests Marilyn Irvin Holt, drew on Americans' growing interest in and awareness of mental health. ${ }^{40}$ That may be true in part, but conference planners also viewed the development of healthy personalities as a way to propagate productive citizens for the sake of community and national prosperity. The national Technical Committee on Fact Finding reported that the midcentury agenda, "quite aside from the individual, humanitarian aspects of the matter," was intended to address the "serious consequences for a society that now more than ever stands in need of efficient workers, clear thinkers, loyal citizens, who are to protect its way of life." 41

In fact, organizers did not actually consider personality to be an aspect of health or character. Rather, it encapsulated the whole person. The fact-finding committee asserted that "the human being does not have a personality; he is a personality." 42 As such, neglecting the personality and neglecting the person was one and the same. Waste resulting from such neglect, the committee argued, would be costly in terms of lost efficiencies, remediation expenses, and moral degradation.

Many believed that such neglect was already occurring. Leonard C. Murray, who chaired Iowa's Research Committee on Health, reported that "without question there has been waste of the potential strength and capacities of children in Iowa. This waste has cost us heavily through problems of delinquency, misfit jobs, inadequate care and opportunity for the mentally and physically ill and many others." 43 A U.S. Children's Bureau pamphlet on the midcentury conference claimed, "Our waste in children is

Parsons and the Carnegie Project on Theory, 1949-1951," Journal of the History of Ideas 71 (2010), 301; Vincent Nowlis to Esther Immer, 6/1/1949, file: Correspondence 1949, box 1, Esther Immer Papers; Vincent Nowlis to Katherine Bain, $6 / 1 / 1949$, ibid. For more on the conference's psychological platform as well as a list of the members of the Technical Committee on Fact Finding, see For Every Child a Healthy Personality: A Digest of the Fact Finding Report to The Midcentury White House Conference on Children and Youth (Washington, DC, 1950), ii.

40. Holt, Cold War Kids, 23.

41. For Every Child a Healthy Personality, 1.

42. Ibid., 3 (emphasis in original).

43. Leonard C. Murray, Report from the Health Committee, Iowa Commission on Children and Youth (Des Moines, 1950), 2. 
great." It encouraged attention to the preparatory task at hand, claiming that "by acquiring new knowledge and putting that to work, we can stop much of this waste." 44 Conference planners operated from the premise that arresting waste was integral to fostering healthy children and communities.

INITIALLY, the ICCY viewed conference planning as an opportunity to revisit the deferred recommendations from the 1940 Conference on Children in a Democracy. Esther Immer recorded that such action might be needed since "many of its recommendations [had] been held in abeyance by war." 45 However, as investigations proceeded, it became apparent that the exigencies of war had altered communities to a degree that called for a substantial reevaluation of issues pertaining to children and youth. Indeed, as Iowa historian Dorothy Schwieder has noted, World War II was a "watershed" of change for the state. ${ }^{46}$

The ICCY decided that it would need to carefully consider changes brought about by wartime employment, military service, and relocations that had separated families, destabilized home life, and altered the patterns of daily living. Historian Lisa Ossian's study on children during World War II, drawn largely from Iowa sources, explains how the war affected children "in profound and often silent ways." Children were encouraged to demonstrate patriotism by collecting scrap, cleaning their plates, and donating their allowance to the war effort. Parenting magazines encouraged mothers to "make partners of their children" in order to decrease the stress and strain of wartime single parenthood. Through radio and print media, and even in schools, war and its images (both real and imagined) permeated children's lives. Ossian explains that for many young Iowans, "carrying on as little soldiers appeared to be the only accepted response." 47 The ICCY's

44. USCB, "Why a Conference?" 2.

45. "Planning Conference," 4.

46. Dorothy Schwieder, Iowa: The Middle Land (Ames, 1996), 279.

47. Lisa Ossian, The Forgotten Generation: American Children and World War II (Columbia, MO, 2011), 117, 44, 122. For more on how war losses affected children, see ibid., 116-31. On disruptions to family life, see Deborah Fink, "World War II and Rural Women," in Iowa History Reader, ed. Marvin Bergman (Iowa City, 2008), 347. 


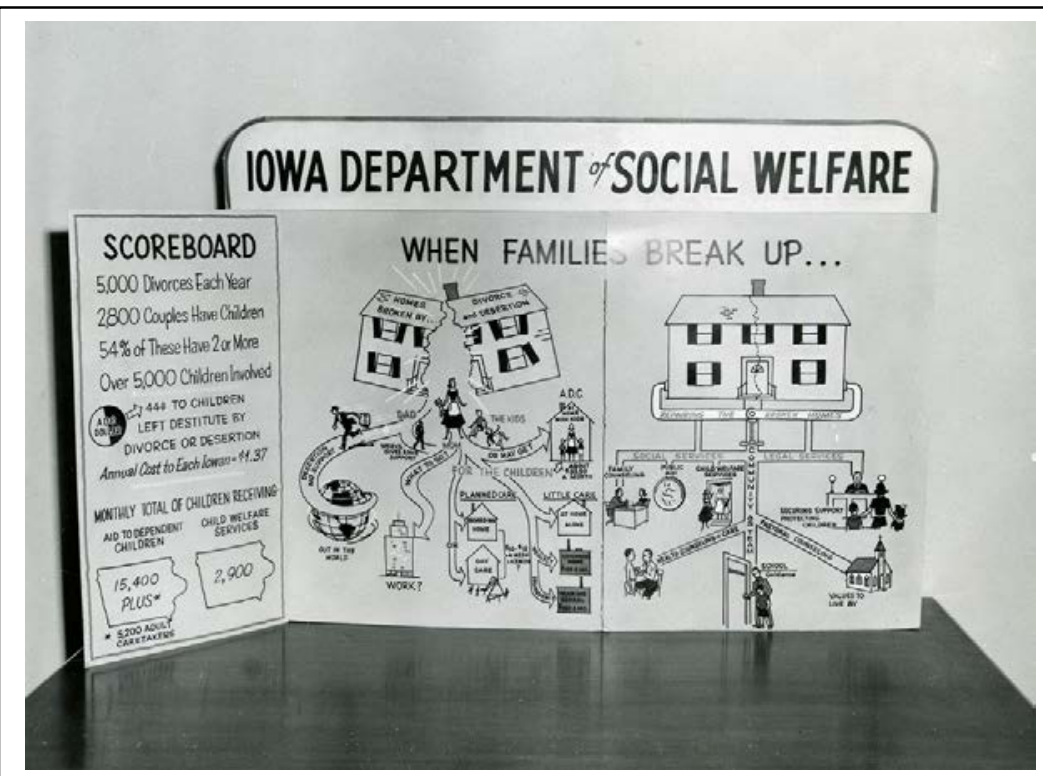

A display at the ICCY's Iowa White House Conference on Children and Youth in Des Moines, sponsored by the Iowa Department of Social Welfare, focused on the effects of divorce on Iowa children. Photo from SHSI-IC.

inquiry into children's lives in 1948 revealed wartime repercussions and highlighted new postwar concerns.

One of those concerns was family destabilization caused by divorce and wartime deaths. The Committee on the Protective Care of Children reported that divorce rates had increased 36 percent since the war. Its findings indicated that more than 5,000 Iowa children per year were touched by divorce. ${ }^{48}$ Although the committee also noted rising birthrates as a point of change, it is clear that committee members did not yet comprehend the extent of the nascent baby boom. Rather, they appeared to find the rise in single motherhood most disconcerting. Research revealed that by early 1950, 2 percent of all Iowa children were born to unwed mothers. ${ }^{49}$ Although the committee's report did not specify the

48. Report of the Committee on Protective Care of Children (Waverly, Iowa, 1950), 1. Dorothy Schwieder, Iowa: The Middle Land, 276, notes that of the 265,000 Iowans (men and women) who served during World War II, 8,400 were killed in action. 49. "Iowa Commission Highlights," 4. 
degree to which this represented an increase over prewar figures, it is clear that committee members considered two-parent family units imperative for children's healthy development. On this, Iowans shared the national consensus that considered the twoparent nuclear family a bulwark against communism..$^{50}$ Based on its reports, the ICCY seemed ambivalent at best regarding the trajectory of Iowa family life. Yet it left no doubt that Iowans needed to devote significant attention and support to fostering healthy family life and home environments as the principal context within which children developed.

The youth labor force was another area of concern. Wartime demand for foodstuffs had brought prosperity to Iowa farmers, but it also dramatically increased demand for agricultural labor at a time when able-bodied farmhands were leaving farms for more lucrative urban-based defense jobs. As the labor force migrated from rural to urban environs, an additional 24,000 Iowans left the state for work elsewhere.51 The exodus of adult workers left opportunities for younger Iowans to demonstrate their patriotic impulse while earning an income (often at the expense of their education). The University of Iowa's student newspaper, The Daily Iowan, reported that during the war, "many a lad and lass" had dropped out of high school "in favor of a lush war job." 52 However, postwar youth unemployment became a considerable problem when returning GIs, postwar industry conversion, and back-to-school campaigns displaced young workers.

The Committee on the Employment of Youth explained that youth unemployment was problematic for a number of reasons. First, during the war, widespread youth employment had changed family provisioning dynamics as a number of families had be-

50. Holt, Cold War Kids, 9. For more on the family as a bulwark against communism, see Elaine Tyler May, Homeward Bound: American Families in the Cold War Era (New York, 1988).

51. Fink, "World War II and Rural Women," 348-51, 356-61; Schwieder, Iowa: The Middle Land, 277-79, 288-89. By 1943, draft boards increasingly granted deferments, and the Food for Freedom program issued "Certificates of War Service" to farmers and hired hands in order to stem the loss of adult male laborers.

52. "Many Iowa Youths Leave Defense Jobs, Return to Schools," Daily Iowan, 9/2/1945. According to a wartime Iowa poll, 34 percent of men and 28 percent of women approved of older teenage boys taking as much as a half-year break from school in order to fill in on farms. Ossian, The Forgotten Generation, 36. 
come dependent on adolescent family members' incomes. Further, many Iowans believed that it was important for youth to learn job skills before leaving high school. The latter point is significant here as the Committee on Education reported that some Iowa communities had experienced high school dropout rates as high as 54 percent by 1950. In its report, the Committee on the Employment of Youth expressed the widely held conviction that "the problem of getting young people started in the world of work is one of society's greatest obligations." The committee claimed that fewer children were learning labor skills at home. As a result, young people entered the labor pool unprepared. It was incumbent upon Iowans, therefore, to provide youth with employment that complemented and worked with educational opportunities so that the young may "become productive citizens." The committee advocated increased vocational training in high schools for those students who did not have an opportunity to work on a farm or in a family business (fewer than one-third of all Iowa high schools offered vocational training programs during the 1948-49 academic year). ${ }^{53}$

Fewer youngsters received workforce training at home partly because the tenor and pace of domestic living had changed as a result of urbanization and new farming methods - both resulted in fewer children raised with traditional rural skill sets. The number of Iowa farms had decreased from 213,318 in 1940 to 208,934 by 1945 . While the number of farms decreased by 4,384 , the total farmed acreage decreased by only 640 acres. ${ }^{54}$ What this reveals is that thousands of smaller family farms were consolidated and absorbed by larger farms during the war, facilitating the trend toward large-scale, postwar agribusiness. Further, many of the remaining family farms mechanized after the war. Mechanization decreased demand for much of children's labor and, consequently, decreased their opportunities to learn those traditionally acquired skills.

To add injury to deprivation, the Committee on Handicapped and Exceptional Children reported a significant rise in

53. Report of the Education Committee (Des Moines, 1950), 2; "Iowa Commission Highlights," 4; Bryan, "Report of Committee on Employment," 1, 3.

54. Agricultural Division, United States Census of Agriculture, 1950, Counties and State Economic Areas: Iowa (Washington, DC, 1952), Section A, p. 3. 


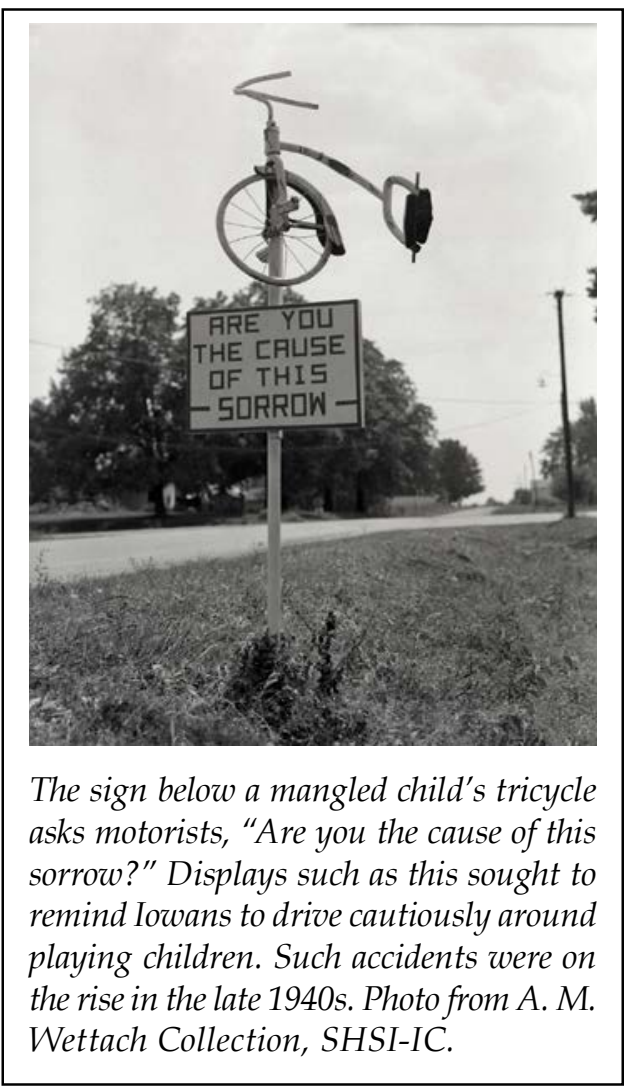

children's injuries, amputations, and even deaths due to mechanized farm equipment and a postwar increase in automobile usage. 55 Such injuries, asserted the Committee on Health, along with communicable diseases like polio, plagued Iowa communities throughout the 1940s and threatened to weaken the nation. "In a democracy," asserted Leonard C. Murray, who chaired the Committee on Health, "good health is of vital importance to

55. J. L. Anderson, “'The Quickest Way Possible': Iowa Farm Families and Tractor-Drawn Combines, 1940-1960," Agricultural History 76 (2002), 681-82. On the modernization of Iowa's agricultural industry in the twentieth century, see Mark Friedberger, "The Modernization of Iowa's Agricultural Structure in the Twentieth Century," in Iowa History Reader, ed. Marvin Bergman (Iowa City, 2008), 375-96. For a detailed discussion of the dangers of farm mechanization, see Derek Oden, "Perils of Production: Farm Hazards, Family Farming, and the Mechanization of the Corn Belt, 1940-1980," Annals of Iowa 73 (2014), 238-68. 
every individual, for the individual is unable to render a maximum service to society, unless he has good health." The committee pointed to the high number of wartime 4-F classifications to demonstrate the connection between children's and adults' health. ${ }^{56}$ Many of the conditions that led to 4-F classifications stemmed from childhood injury, malnutrition, or disease. Committee members argued that preventable poor health was a significant cause of waste among the population.

World War II had also brought Iowa's educational system to a crisis point. The Education Committee's investigation revealed low educational standards and inadequate facilities, but the severe teacher shortage seemed to be the greatest concern. During the war thousands of teachers nationwide left education for military service or higher-paying defense jobs. ${ }^{57}$ The problem continued well into the postwar years. The ICCY Education Committee predicted that Iowa would have a shortfall of 675 elementary school teachers for the 1950-51 academic year. 58 The committee recommended maximizing resources by consolidating schools. Low student-to-teacher ratios were considered a significant component for the successful cultivation of young minds. As such, the committee also recommended state support for university-led efforts to recruit and educate teachers. ${ }^{59}$

The ICCY considered juvenile delinquency to be a pressing issue. Drawing on 1947 data, the Committee on Care and Re-

56. Murray, Report from the Health Committee, 2. In late summer and autumn of 1950 Iowa saw a sharp rise in polio cases. The topic was much on the minds of Iowans as they met to discuss health issues. "Polio Cases Reach Record High of 38 as 10 More Enter," Daily Iowan, 8/30/1950; "Seventh Polio Death of Year Reported at SUI Hospital," Daily Iowan, 8/30/1950; "Six New Polio Cases Admitted; Total Set at 43," Daily Iowan, 8/31/1950; "Physical Therapy Aids PolioStricken Muscles," Daily Iowan, 9/3/1950. Army 4-F classifications were a national concern during both world wars. The September 17, 1944, issue of Yank Magazine: The Army Weekly reported 3,798,000 nationwide rejections for military duty as a result of 4 -F classifications.

57. Ossian, The Forgotten Generation, 34. Nationwide, the 1943-44 academic year saw a teacher shortage of 75,000, and 2,000 rural school closures. Ossian also discusses how American schools adopted the "Education for Victory" curriculum that strayed from standard pedagogy to promote patriotism, nationalism, and democracy. Ibid., 22-39.

58. “Record Number Returns to Local Schools," Daily Iowan, 9/12/1950.

59. Report of the Education Committee, 3. 
habilitation of Delinquent Youth reported that 2,223 minors between the ages of 3 and 18 years (the majority 15 to 16 years old) had been brought before the courts that year, resulting in 766 youths being committed to correctional facilities. The committee noted that urban juvenile court cases outnumbered rural cases by five to one and that male delinquency was four times likelier than female. Female delinquency, at least in terms of sexual transgression, seems to have been treated as a fringe of mental illness. The Committee on Handicapped and Exceptional Children reported 25 "emotionally disturbed youth" committed to state facilities, with only illegitimate births, early marriage, and divorce catalogued as the reasons for commitment. Perhaps some of these youth were committed to institutions for other mental health reasons, but the heart of the issue seemed to be their abortive or premature transition to adulthood. Chairman Murray reported that a number of such commitments could be prevented with timely mental health intervention. He claimed that at least 7,500 young Iowans were in need of comprehensive clinical assessments that were already available to adults. It would be "pennywise and pound foolish," he warned, to continue to deny services to children that the state provided to adults. ${ }^{60}$

The Committee on Care and Rehabilitation of Delinquent Youth also used surveys to attempt to determine the root causes of delinquency. Based on those questionnaires, the committee concluded that poor housing, broken homes, "poor quality movies, cheap literature, and sensuous radio programs," along with schools' inability to deal with the "needs of [the] sub-normal child of low intelligence" were but secondary factors in delinquency cases; such factors exacerbated but did not cause the problem. Rather, they reported, parental neglect and inadequate police presence were the primary causes and "an invitation to delinquency." In their defense, a number of police officers redirected blame toward pool hall proprietors and inattentive parents. They claimed that law enforcement was less effective when communities and parents tolerated bad behavior. ${ }^{61}$

60. Walter Albin Lunden, Delinquent Youth in Iowa: Report of the Committee on Care and Rehabilitation of Delinquent Children in Iowa (Des Moines, 1950), 12, 6-7; "Mentally Sick Children Lack Help: Report," Cedar Rapids Gazette, 11/27/1950. 61. "Report ... on Care and Rehabilitation," 30-31. 
Youth themselves also had much to say on the topic. Claiming a dearth of recreational facilities, they cited churches and overly moralistic adults as obstacles to "youth centers, as [such adults] disapprove of dancing, bingo, cards and so many things." One youth complained that adults just didn't understand kids' desire for "good, clean fun." One teenager from Fort Madison asserted that class, race, and school rivalries created "a hotbed of many bad situations." Many youth also remarked that inadequate "attention to boy-girl relationships" resulted in promiscuity and teen pregnancy. In the absence of formal sex education, some claimed that their primary education came from observing animals. One young respondent from Clemons, Iowa, wrote that proper education could "make sex something more than animal excitation." 62

Receptivity to such surveys demonstrated one of the significant ways that the 1950 conference differed from previous meetings. The extended preliminary planning period allowed for reports that incorporated input from the young. As conference planners and research committees strove for greater inclusion, they modeled a kind of democratic action intended to encourage young people while fostering their journey toward responsible citizenship.

In addition to expressing concern for the rates and causes of juvenile delinquency, the Committee on Care and Rehabilitation of Delinquent Youth also examined recidivism and the poor treatment of minor inmates. The committee found that incarceration facilities often served as incubators of crime when juvenile offenders were housed with the adult convict population (many of whom were reportedly lifelong offenders). ${ }^{63}$ The committee asserted that "juvenile acts constitute a mirror in which society may see the adult world in miniature." Therefore, chronic juvenile recidivism, it reported, should be viewed as mimicry of a debased incarcerated adult world. Effective rehabilitation, it argued, required separating delinquent minors from hardened adult criminals and providing positive role models. ${ }^{64}$ Misguided lead-

62. Ibid., 32-34; Report of the Committee on Community Facilities and Recreation (Cedar Rapids, 1950), 9-10.

63. "Report ... on Care and Rehabilitation," 5-6. A survey of native-born incarcerated Iowa men from across the state revealed that 46 percent had committed their first offenses between the ages of 10 and 19.

64. Ibid., 5 . 
ership at many institutions compounded the problem by discontinuing educational programs during the war in order to use young inmate labor to fulfill war contracts. ${ }^{65}$ Hence, the committee argued, youth correctional facilities had become morally degenerate environments that lacked opportunities for rehabilitation. Additionally, reports regarding the ill treatment of juvenile inmates had surfaced by the end of the war.

The 1945 Eldora riots brought this matter to Iowans' attention. On August 29 young inmates at the Eldora State Training School for Boys unleashed their frustration and anger after guards beat 17-year-old Ronald Miller to death. The boys ransacked the dining hall and nearly 200 escaped over the next few days. Conditions there were so riotous that the governor called out the State Guard to quell the unrest and capture and return escapees. Upon investigation, one newspaper reported that the Eldora reform school was a "Dickensian institution" complete with fences, barred windows, solitary confinement cells, and regular beatings. ${ }^{66}$ Five years later, in September 1950, the ICCY Committee on Care and Rehabilitation of Delinquent Youth remarked that judges still hesitated to commit boys to Eldora until conditions improved. ${ }^{67}$

THROUGHOUT the summer and autumn of 1950, the ICCY worked tirelessly to publicize the upcoming midcentury conference, promote its work among the general population, and gather final contributions from communities. Members of the executive board traveled throughout the state giving talks and soliciting feedback at community and associational group meetings. There was a "Conference on Child Development and Parent Education"

65. "Report of the Board of Control of State Institutions," 6, file: Iowa Commission on Children and Youth, box 2, Esther Immer Papers.

66. “Employe Says Eldora as Bad as Nazi Camps," Daily Iowan, 9/1/1945.

67. "Report on ... Care and Rehabilitation," 19. Attempting to divert attention from his own culpability, Assistant Superintendent Darrel T. Brown claimed that there had "been a spirit of general unrest for some time." But witnesses claimed that Miller's death sparked the riot. An investigation revealed that Miller died when two guards beat him to death with a blackjack and leather straps. “150 Boys Escape from Eldora," Daily Iowan, 8/30/1945; “41 Escaped Boys from Eldora School Still Hiding Out," Daily Iowan, 8/31/1945; "Employe Says Eldora as Bad"; "44 More Escape from Eldora Despite Iowa State Guardsmen," Daily Iowan, 9/2/1945. 


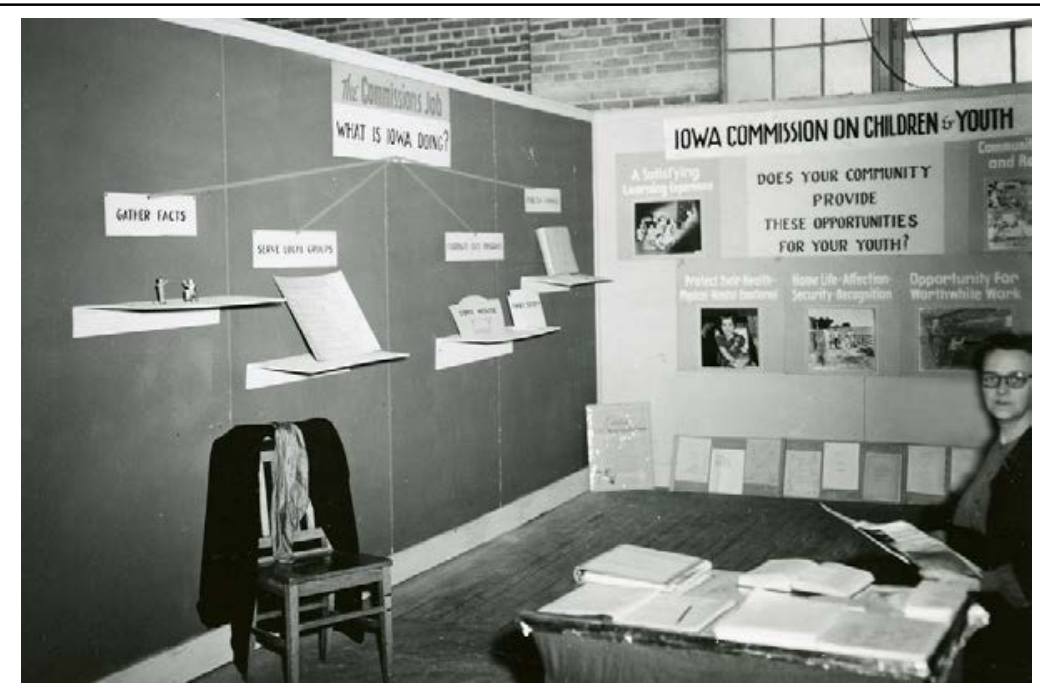

Volunteers staffed the ICCY booth at the Iowa State Fair, August 25September 1, 1950. Photo from SHSI-IC.

at the University of Iowa's Child Welfare Research Station on June 20-21, 1950. Louis de Boer, the national conference director of State and Local Action, gave the keynote speech, and ICWRS faculty Ralph J. Ojemann and Ruth Updegraff disseminated information and solicited additional input in afternoon workshops. ${ }^{68}$ From August 25 to September 1, volunteers from various recreational agencies, such as the YMCA, Boy Scouts, Jewish Community Center, and Salvation Army, staffed the ICCY booth at the Iowa State Fair, which displayed information and solicited input from Iowans. ${ }^{69}$ The ICCY also staffed a booth at the 1950 Parent Teacher's Association Convention in Des Moines, which displayed posters intended to convey a number of points. The

68. "Judge Matthias to Attend Conference on Children," Cedar Rapids Gazette, 5/23/1950; "Child Personality Health Will Be Conference Theme," Cedar Rapids Gazette, 5/29/1950; "Child Welfare Conference to Open Tuesday," Cedar Rapids Gazette, 6/18/1950.

69. "Agenda for Iowa State Fair," August 25-September 1, 1950, file: Iowa Commission on Youth Memoranda, box 2, Esther Immer Papers; "Children's Day as Iowa State Fair Opens," Daily Iowan, 8/26/1950. 


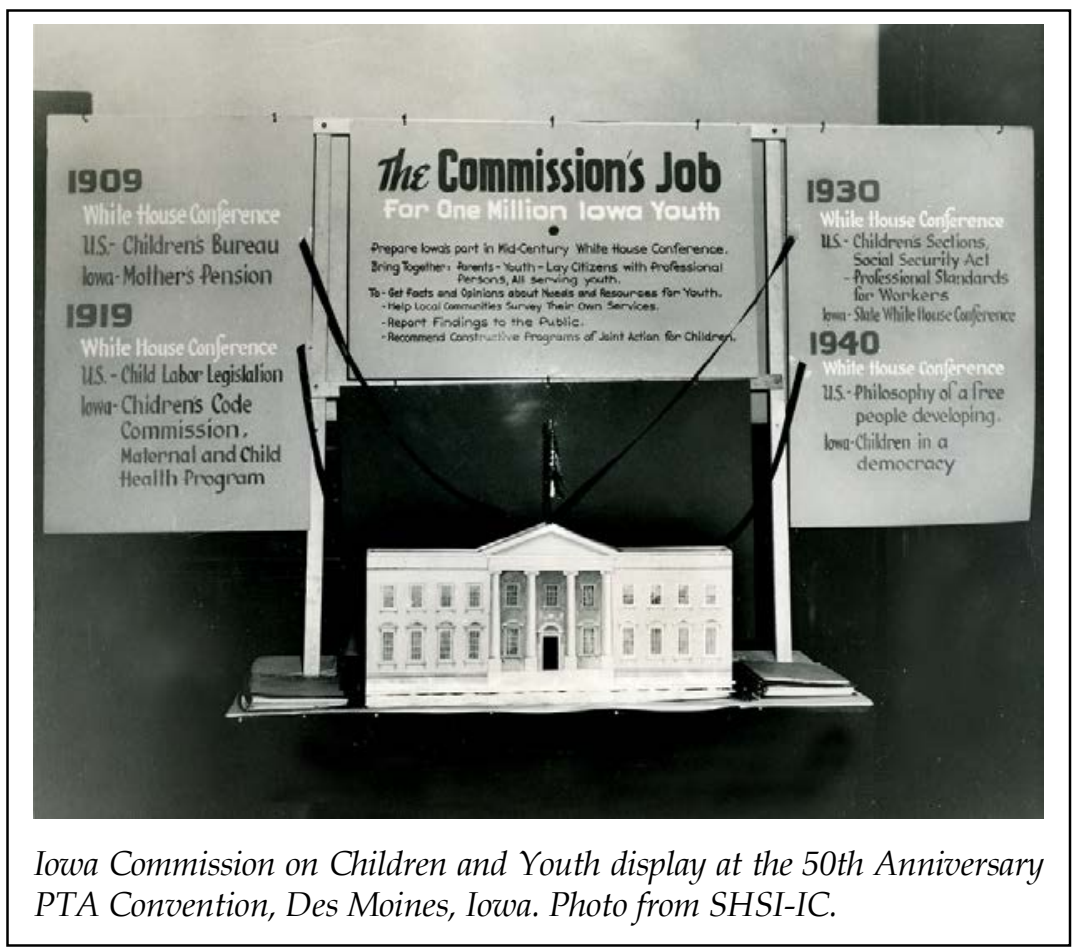

posters summarized previous White House Conference themes, emphasized the preparatory work leading to the midcentury conference, informed the public of the ICCY's role in the forthcoming conference, and provided brief summaries of major issues.

On October 20 the ICCY held a statewide meeting called the Iowa White House Conference on Children and Youth at Drake University in Des Moines. The conference was open to the public and, according to ICCY executive director Esther Immer, was intended as one last effort to solicit input from concerned citizens throughout Iowa "on the subject closest to their hearts." In total, 430 Iowans attended the state conference, including 135 youth from high schools and colleges. ${ }^{70}$ Immer noted that all of these efforts served to draw communities together. United in purpose,

70. Esther Immer to A. Whittier Day, 9/11/1950, file: Correspondence 1950, box 1 , Esther Immer Papers; Letter of invitation, Governor William S. Beardsley to Iowa citizens (conference program attached), 10/5/1950, ibid.; "Iowa Conference on Youth Will be Held at Drake University," Cedar Rapids Tribune, 9/21/1950. 


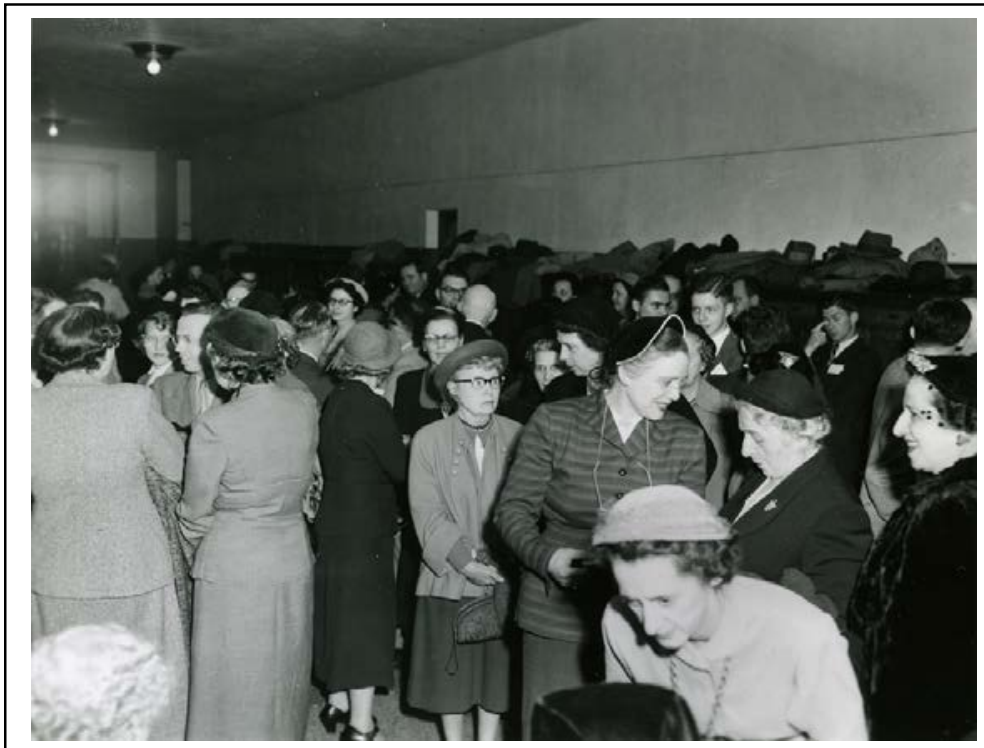

Attendees pack a room at the Iowa White House Conference on Children and Youth at Drake University in Des Moines in October 1950. Photo from SHSI-IC.

Iowans sought to prepare "their children for a happy life and fulfillment of the duties of citizenship in a world upset by fears and strife." 71

THE OVERCAST SKY on the morning of December 3, 1950, did not dampen the spirits of the more than 6,000 delegates who gathered for the Midcentury White House Conference on Children and Youth at the National Guard Armory in Washington, D.C. Indeed, many a midwestern delegate must have found the moderate temperature and occasional light drizzle a welcome relief from the converging weather fronts that had brought freezing temperatures to Iowa and freak tornadoes to Illinois and Arkansas only the day before. ${ }^{72}$

71. Immer, "Proposed Report."

72. "The Weather," Washington Post, 12/3/1950; J. R. Fulks and Clarence D. Smith Jr., "A December Storm Accompanied by Tornados," Monthly Weather Review (December 1950), 220-25. 
The diverse group of delegates represented every American state and territory. They came from cities and rural communities. They represented government agencies, community organizations, and a variety of professions. They were old and young and of different racial groups and religious affiliations. Yet all sought an opportunity to contribute to the conversation and influence the outcome of the much anticipated event.

The turnout was so great that the crowds nearly overwhelmed the national committee. Conference executive director Melvyn Glasser observed that delegates were "stacked up three deep" trying to get into workshops. Oscar R. Ewing, who chaired the national committee, worried that the sheer number of participants, the multitudinous perspectives, and the wide range of issues might hinder efforts toward consensus. ${ }^{73}$ While it complicated logistics on the ground, the unprecedentedly high attendance testified to the success of preconference planning efforts. President Harry S. Truman declared it a "unique demonstration of our democracy's concern for children. . . . Proof that our American tradition of free exchange of fact and opinion is a living, working force." 74 Indeed, it was heartening for most to see so many who had taken their charge so seriously.

The protracted planning period had served to heighten expectations. At daily breakout sessions delegates eagerly debated topics such as education, religion, federal funding, segregation, war mobilization, and the atomic bomb. Impassioned discussion and lengthy debates delayed some resolutions, such as that on the role of religion in public schools, by as much as five hours. ${ }^{75}$

Ultimately, the majority passed a resolution that affirmed the separation of church and state by voting that religion should not be taught in public schools. Iowa Superintendent of Schools Clyde Parker spoke on behalf of the resolution. He acknowledged that

73. Dorothea Andres, "Youth Needs Are Our Needs," Washington Post, 12/4/ 1950; Holt, Cold War Kids, 12; "Women's Club Members at Capitol Conference," Cedar Rapids Gazette, 12/5/1950; "Iowa in Washington," Cedar Rapids Gazette, 12/10/1950.

74. Richards, Proceedings, 2-3.

75. "Parley Advanced Youth-Adult Understanding, Delegates Say," Washington Post, 12/7/1950; Dorothea Andrews, "Youth Parley Votes 3 Major Resolutions," Washington Post, 12/8/1950; "Statements by Delegates Challenged," Washington Post, 12/7/1950. 
religion was a "wonderful thing" for many people but expressed the conviction that "religious instruction must not be offered in a public, tax-supported school."76

Another major point of contention, and sign of the times, was the discussion of children and television. Many delegates felt that modern media negatively influenced young people's behavior and morals. However, Robert Saudak, father of four and a vicepresident with the American Broadcasting Company, defended television and emphasized parental responsibility in monitoring children's viewing habits. Dean Bruce Mahan of the University of Iowa agreed with Saudak. Citing his own research, Mahan argued that when it came to television, "the good far outweighs the bad," and that it was parents' responsibility to direct their children toward positive options. ${ }^{77}$

Youth participation at the national conference was a priority for organizers. It was the first time that young people had been invited to participate in a national conference on children and youth. Organizers viewed it as an opportunity to initiate young Americans into responsible citizenship. Youth embraced the moment but held adults to high standards of leadership. Teen Iowa delegate Peggy Ann Leu expressed exasperation at the lengthy, heated debates, and claimed that she had picked up "only a few large gold nuggets panned from inspirational, but sometimes superfluous streams" of discussion. ${ }^{78}$ Leu's critique appears to have been based on a spectator's perspective, but many newspapers reported youths' active involvement in a number of discussions, particularly on the topic of racism.

Some youth lambasted organizers for permitting segregated conference lodging. Five hundred young delegates took it upon themselves to model the change they hoped to see when they lodged together in racially integrated accommodations at nearby Fort Meyers. While many adults were taken aback by the youths'

76. “Keep Schools Religion-Free, Parker Says," Cedar Rapids Gazette, 1/30/1951. 77. "Parent Must Censor Video, A Father Says," Cedar Rapids Gazette, 12/6/1950. 78. "Responsibility Asked by Youth," Cedar Rapids Gazette, 12/6/1950; "Report by Youth Delegate Peggy Ann Leu of the Iowa Commission to the Midcentury White House Conference on Children and Youth: Impressions and Repressions at Washington, D.C.," file: White House Conference on Children and Youth, box 3, Esther Immer Papers. 
boldness, Chicagoan Dr. Allison Davis lent her support, arguing that, as a result of Jim Crow practices, most minority children and youth were "wasted in the schools, in the armed services, and in industry." "This Nation," she contended, "can no longer afford waste." Iowan Clyde Parker concurred, warning delegates that "unless something is done relative to racial discrimination, we are liable to end up on the rocks of democracy." 79 In the end, the conference consensus was that minority children did not have a "fair chance at developing a healthy personality" and that something must be done.

Delegates' exuberant participation on the issues of television, religion in schools, and racism, among others, clearly evidenced what national organizers had anticipated would be "a citizens' conference" that was "grounded in the principles of democratic action and fashioned by the best thinking and free discussion of representative citizens." 80 It was a fruitful start to what promised to be an ongoing national conversation.

THE NATIONAL CONFERENCE was deemed a grand success, but what was accomplished at the state and community level should be considered equally important. Through earnest hard work and community investment Iowans had taken the first steps toward conserving their children; that is, they set out to identify the causes of waste - wasted health, wasted potential, wasted personality - and began to devise ways to construct environments conducive to the positive growth and development of individual young Iowans.

During the planning stage Iowans drew on language and imagery (such as crops, yields, waste, and conservation) that were rooted in a Jeffersonian approach to agrarian nation building and notions that sprang from the early twentieth-century conservation movement. Such an approach had spoken to the still largely

79. "White House Youth Confab Smacks Jim Crow," Chicago Defender, 12/6/ 1950; "Negroes Play Big Roles at Mid-century Confab," Chicago Defender, 12/6/ 1950; Dorothea Andres, "U.S. Wastes Manpower, Parley Told," Washington Post, 12/6/1950; "U.S. Public Education System Not Democratic, Says Dr. Davis," Washington Post, 12/10/1950; "Keep Schools Religion-Free."

80. USCB, "Why a Conference," 2; Platform Recommendations, i. For a more expansive discussion of the conference, see Holt, Cold War Kids. 
agrarian nation in 1909, when at the first National Conservation Conference Mrs. J. Ellen Foster compared growing children to saplings. She had argued that child labor wasted potentially useful future resources when children's strength and energy were expended before their prime. Subsequently, Theodore Roosevelt preached the "conservation of childhood" in support of antichild labor campaigns. Child welfare reform activists of the Progressive Era applied the phrase to education, health care, illegitimacy, and parenting. The first head of the Iowa Child Welfare Research Station, Carl Seashore, claimed that "the problem of child conservation is quite analogous to the problem of the forest." He assured state legislators that the ICWRS would find solutions through child welfare research. ${ }^{81}$

The philosophy and practice fit with Iowa's extensive agricultural heritage and what historian Lewis Atherton describes as the Midwest's "cult of the immediately useful and practical." 82 Scholars have tended to interpret this regional attitude strictly in terms of financial gain, but it may be argued that Iowans' investment of time and resources in investigating child welfare reveals deeply held convictions that the careful cultivation of the next

81. Laura Lovett, Conceiving the Future: Pronatalism, Reproduction, and the Family in the United States, 1890-1938 (Chapel Hill, NC, 2007), 110; Theodore Roosevelt, The Conservation of Childhood, National Child Labor Committee pamphlet no. 163 (New York, 1911); "Doings of the Women's Clubs: Lectures Before the Woman's Political League, an Alameda Teacher on the 'Conservation of Childhood,'," San Francisco Chronicle, 1/18/1912; Kate Waller Barrett, "Protection for the Innocents," Washington Times, 3/11/1914; "The Fight for School Nurses Is Taken Up," Washington Herald, 3/25/1914; "Maternity Insurance to Aid Child Welfare: Health Official Urges Conservation of Womanhood and Childhood," Labor Journal, 4/26/1918; Smuts, Science in the Service of Children, 128; Carolyn Merchant, "Women of the Progressive Conservation Movement: 1900-1916," Environmental Review 8 (1984), 75.

82. Lewis Atherton, Main Street on the Middle Border (Bloomington, IN, 1984), 111-15. According to Dorothy Schwieder, Iowans judged activity according to the "cult of the immediately useful and practical," that is, whether it had "immediate, practical utilitarianism" and could be justified financially. This, she explains, also had a gendered component in that men's actions were judged accordingly more often than those of women or children. Nonetheless, I contend that such beliefs so thoroughly permeated society by the mid-twentieth century that they should be considered a motivating factor writ large: Schwieder, "Iowa: The Middle Land," in Iowa History Reader, ed. Marvin Bergman (Iowa City, 2008), 7. See also William Barillas, The Midwestern Pastoral: Place and Landscape in Literature of the American Heartland (Athens, OH, 2006), 34. 
generation would yield abundantly. To a considerable extent, Iowans preferred to find solutions and manage their affairs directly rather than rely on federal direction. ${ }^{83}$ ICCY's preconference investigations resulted in a number of remedial efforts at the state and community levels even prior to the midcentury conference: Iowans reassessed laws pertaining to children and held a conference on youth recreation, and many individuals voluntarily committed their time and talents to community youth outreach.

An enormous advance on the issue of juvenile corrections came immediately following the conference when Hollis Miles assumed leadership as the superintendent of the Eldora juvenile correctional facility. He took an individualized, psychologybased approach to the problem of delinquency and implemented tactics in line with the conference position. Drawing on the language of conference delegates, Miles claimed that the "delinquent child was an unhappy child" who grew into a "lopsided" personality. By 1951, through a program that fostered troubled adolescents' individual personal growth and self-awareness, Miles decreased the once notorious reformatory's population from 600 to 200 with only a 15 percent recidivism rate. ${ }^{84}$ State Superintendent of Public Schools Clyde Parker reported that he, too, had come to realize that more should be done to bring "youth into the planning of community activities and community programs." Consequently, he conferred with high school students "regarding problems and wants" on a monthly basis. ${ }^{85}$ It is clear that the preparatory period brought Iowans to a concerted and communal focus on their children.

Post-conference action at the state level differed in tone and purpose from that at the federal level. In evaluating the significance and outcomes of the Midcentury White House Conference on Children and Youth, one should not lose sight of additional

83. Report of Committee on Community Facilities, 6; "Summary of Recommendation Approved by Citizens Attending," 10/20/1950, p. 2, file: Minutes 1949-1956, box 2, Esther Immer Papers.

84. "Good Parents Can Learn a Lesson from Bad Boys," St. Petersberg Times, $7 / 29 / 1951$.

85. "Youth Affairs and Salaries Discussed by School Board," Cedar Rapids Gazette, 12/19/1950; "Social Planning Group to Hear Clyde Parker," Cedar Rapids Gazette, 1/21/1951; "Dr. Ojemann and Clyde Parker in Education Report," Cedar Rapids Gazette, 1/28/1951. 
concerns that occupied the minds of the nation's politicians and strategists. Cold War concerns motivated a federal response that disregarded attention to the individual in favor of programs intended to foster the mass production of a homogenous American citizenry. Just as materiel production gave the Allies an edge during World War II, the production of loyal citizens, it was believed, would trump Cold War communism.

Historian Dorothy Schwieder claims that the Korean conflict "seemed to have only minimal impact on [Iowa] as a whole," but the international struggle was actually foremost in the minds of most Americans that first week of December 1950. In the days preceding the conference, newspaper headlines announced that the Chinese People's Volunteer Army had routed a United Nations military offensive along the Ch'ongch'on River in North Korea, driving troops (largely South Korean and American) in a southward retreat across the 38th Parallel. 86 The surprise Communist counteroffensive crippled American military morale, repelled General MacArthur's "Home-by-Christmas" offensive, and heightened conference goers' awareness that a protracted police action could result in the draft of many of the youth they hoped to preserve. ${ }^{87}$

President Truman substantiated their concerns when he informed delegates that the nation was in the throes of a lifeand-death struggle. The Communist military threat, he asserted,

86. Schwieder, Iowa: The Middle Land, 286; David Halberstam, The Coldest Winter: America and the Korean War (New York, 2007), 389; "Allies Lose Ground All Along Front: Mac Calls Generals in Field to Tokyo for Urgent Meeting," Cedar Rapids Gazette, 11/28/1950; "The Korean War: Communists Drive Americans and South Koreans Back in the Northwest," New York Times, 11/28/1950; "The Korean War: Communists in Intensified Attacks Continue Driving Back U.N. Forces in Korea," New York Times, 11/29/1950; "Two Big Questions in Korea Debacle Confront War Strategists," Los Angeles Times, 12/1/1950; “U.S. Isolated and Alone in Midst of Korean Crisis," Los Angeles Times, 12/2/1950.

87. General MacArthur had confidently proclaimed that his Home-for-Christmas offensive "should for all practical purposes end the war, restore peace and unity to Korea, enable prompt withdrawal of United Nations military forces, and permit the complete assumption by Korea of full sovereignty and international equality." Quoted from "The Nation," Time, 12/4/1950, 22. See also Halberstam, The Coldest Winter, 389; and "Korean Victory before Christmas Foreseen in MacArthur's Offensive," Los Angeles Times, 11/25/1950. By December 1, the defense department called for 50,000 draftees in February 1951. "February Draft of 50,000 Asked," Cedar Rapids Gazette, 12/1/1950. 
necessitated full support for the United Nations' agenda and required immediately strengthening U.S. military defenses. "This will change the lives of our young people," he warned. "A great many of them will have to devote some part of their lives to service in our Armed Forces or other defense activities. In no other way can we insure our survival as a nation." 88

Delegates who gathered at the conference intent on devising peace through well-balanced, psychologically healthy children felt at odds with the idea that they were on the verge of World War III. While NCCY Executive Director Oscar Ewing fervently asserted that the conference was "a platform of action and of hope," Truman advised that "nothing this conference can do will have greater effect on the world struggle against communism than spelling out the ways in which our young people can better understand ... why we must fight when necessary to defend our democratic institutions." 89 As historian Marilyn Irvin Holt contends, federal policy had less to do with concern for children and more with building a bulwark against "the threat of Soviet superiority." " 90 As such, post-conference federal initiatives on children's health, education, and well-being aimed to mobilize youngsters en masse to face down communism. That goal superseded the careful cultivation of healthy individual personalities.

BEGINNING IN 1947, Americans nationwide brought their grassroots efforts to bear on preparing for the Midcentury White House Conference on Children and Youth. Their success stemmed largely from what Iowa conference delegate R. Kent Martin called the "realization . . . by adults as a whole, not parents alone ... that all children are the responsibility of all adults." 91 What many grassroots activists sought at the midcentury conference

88. Harry S. Truman, "Address before the Midcentury White House Conference on Children and Youth," 12/5/1950, online at the Harry S. Truman Library, Public Papers of the Presidents: Harry S. Truman, 1945-1953, www.trumanlibrary.org/publicpapers/index.php?pid=989; "Truman Says Country Must Support U.N.", Cedar Rapids Gazette, 12/5/1950.

89. Platform Recommendations, i; Truman, "Address Before the Midcentury White House Conference."

90. Holt, Cold War Kids, 80.

91. Andres, "Youth Needs Are Our Needs." 
was a like-minded group of Americans who had pledged to make children a priority within their own communities. That goal was realized to a large degree. Further, Iowans' efforts to raise awareness within their own state led to many local initiatives focused on building community through healthy children. Delegates' warnings that illiteracy, poor health, delinquency, and racism threatened to waste the nation's youngest human resources hit a national security nerve amid heightened Cold War tensions. Many solutions that stemmed from conference recommendations opened the door to federal intervention in American children's lives on an unprecedented scale. ${ }^{92}$ As the federal government increasingly intervened in American children's lives through funding, legislation, and nationwide programs and initiatives, it began to incubate what it hoped would become the arsenal of democracy against Cold War threats.

The Midcentury White House Conference on Children and Youth was significant as it was the first time that Americans acknowledged, on a grand scale, children's importance as future citizens - the producers, consumers, and defenders of the nation. As scholars such as those from the ICWRS argued from a psychological, sociological, and anthropological standpoint that children's environmental conditions significantly shaped children as personalities, the science of child development gained new import in relation to the Cold War struggle. The conference increased the visibility of issues surrounding childhood and linked them to national politics in such a way that state and federal action resulted - no small feat as such issues were largely absent from the national agenda through the 1930s and 1940s. 93

Viewing the midcentury conference through the lens of an individual state's pre-conference planning activities also highlights the decentralized and democratic nature of the 1950 conference. It was the first time that the national conference welcomed such grassroots contributions. Iowa approached healthy childhood per-

92. For an in-depth discussion of Cold War federal policies and legislation pertaining to American children, see Holt, Cold War Kids.

93. For a discussion of the absence of children and youth in national policies in the 1930s and 1940s, see Leroy Ashby, "Partial Promises and Semi-visible Youths: The Depression and World War II," in American Childhood: A Research Guide and Historical Handbook, ed. J. M. Hawes and N. R. Hiner (Westport, CT, 1985), 489-531. 
sonality development from a perspective rooted in an agrarian philosophy - a philosophy widely embraced until Cold War concerns forced a more industrial, mass-production approach. Many Cold War policy makers came to advocate standardized, streamlined, and large-scale application of programs and initiatives that articulated a specific type of patriotic citizen who would produce, consume, and fight for the American way of life. Consequently, delegates' pacific agenda, which advocated individual personality cultivation for the purpose of peaceful global leadership, was largely subsumed within the industrialized exigencies of a bellicose period. 